\title{
Electrooxidation and Low-tech Determination of Pantoprazole on a Disposable Pencil Graphite Electrode by the use of Cationic Surfactant
}

\author{
Pinar Talay Pinar \\ Van Yuzuncu Yil University, Faculty of Pharmacy, Department of Analytical Chemistry, 65080 Van, Turkey \\ *Corresponding author: E-mail: ptalay@gmail.com \\ Tel: 905057649740
}

Received: 06-28-2019

\begin{abstract}
The electrochemical oxidation of pantoprazole, a selective proton pump inhibitor, was studied in aqueous as well as aqueous/surfactant media at a disposable pencil graphite electrode using cyclic and adsorptive stripping voltammetric techniques. The sensitivity of the stripping voltammetric measurements was significantly improved when the cationic surfactant, cetyltrimethylammonium bromide (CTAB) was present in the neutral electrolyte solution. For analytical purposes, well resolved voltammetric peaks at $+1.05 \mathrm{~V}$ (versus $\mathrm{Ag} / \mathrm{AgCl}$ ) were obtained in Britton-Robinson buffer at $\mathrm{pH} 7.0$ containing $3 \times 10^{-4} \mathrm{M}$ CTAB using square-wave stripping mode (after $30 \mathrm{~s}$ accumulation at open-circuit condition). The process could be used to determine pantoprazole concentrations in the range of $2.4 \times$ $10^{-8}-7.1 \times 10^{-7} \mathrm{M}\left(9.2-272 \mu \mathrm{g} \mathrm{L}{ }^{-1}\right)$ with a detection limit of $7.0 \times 10^{-9} \mathrm{M}\left(2.7 \mu \mathrm{g} \mathrm{L}^{-1}\right)$. The proposed method was applied to the determination of pantoprazole in pharmaceutical formulation and in the spiked human urine samples with acceptable recoveries.
\end{abstract}

Keywords: Pantoprazole; stripping voltammetry; pencil graphite electrode; cationic surfactant; drug; human urine

\section{Introduction}

Pantoprazole (PAN) (Fig. 1) is a substituted benzimidazole derivative which belongs to proton pump inhibitors (PPI). PAN inhibits the acid secretion in the stomach via the specific effect on proton pumps of parietal cells. It was developed for the treatment of acid-related gastrointestinal disorders. PAN is a weak base that is converted to its active form by gastric acid before affecting on the proton pump. The stability of the compound in aqueous solution is $\mathrm{pH}$-dependent. Its degradation rate increases with decreasing $\mathrm{pH}$. At ambient temperature, the degradation half-life is approximately $220 \mathrm{~h}$ at $\mathrm{pH} 7.8$ while it is approximately $2.8 \mathrm{~h}$ at $\mathrm{pH} 5.0$. PAN is extensively metabolized in the liver. The main serum metabolite is formed by demethylation at the 4-position of the pyridine ring, followed by conjugation with sulphate. ${ }^{1-4}$

Several techniques have been developed to estimate PAN in its bulk form, pharmaceutical and biological matrices, including liquid chromatography with different detectors, ${ }^{5-12}$ UV-spectrophotometry, ${ }^{13-15}$ and capillary electrophoresis. ${ }^{16,17}$

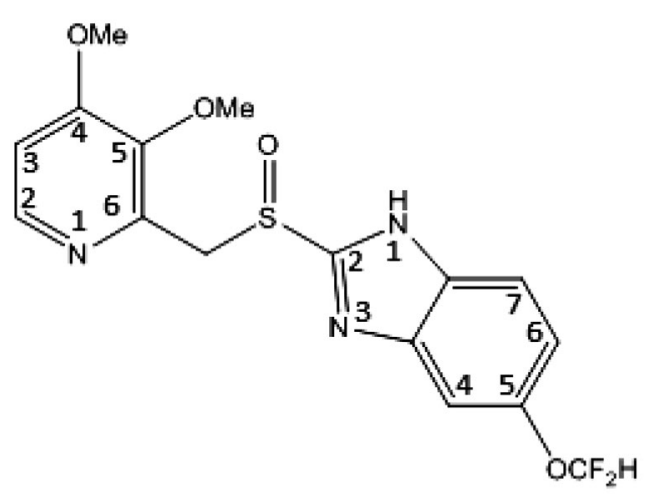

Figure 1. Structure of pantoprazole

Electrochemical assays such as voltammetric methods have been widely used for drug analysis due to their sensitivity, simplicity, cheapness and rapidity. In some studies, hanging mercury drop electrode was applied to the determination of PAN based on its electrochemical reduction. ${ }^{18-20}$ The literature survey states that various bare solid electrodes such as carbon paste electrode, ${ }^{21}$ glassy 
carbon electrode, ${ }^{22,23}$ edge-plane pyrolytic graphite electrode, ${ }^{24}$ and pencil graphite electrode ${ }^{25,26}$ have been exploited for determination of PAN using its oxidative behaviors. On the other hand, some other papers published recently involve the use of modified electrodes for its voltammetric quantification. ${ }^{27-29}$ The analytical performance of the reported electrodes will be discussed later in detail.

In recent years, pencil graphite electrodes (PGEs) have been successfully applied to the electroanalysis of various types of inorganic and organic compounds from very different matrices. In this manner, commercially available graphite pencil leads have been used as electrode materials which present high electrochemical reactivity, good mechanical stability, disposability, low cost, low technology, and ease of modification. ${ }^{30-32}$ The pencil leads are produced by dispersion of natural graphite (major component) into a mixture of clay and polymeric wax followed by heat treatment. Their hardness is commercially modified by varying the graphite and clay ratios. The selection of the correct pencil hardness is also important in the analysis carried out by using PGE. ${ }^{33}$

On the other hand, the adsorption features of surfactants can modify and control the properties of electrode surface, and consequently enhance the sensitivity and selectivity of electrochemical response. Additionally, the medium containing surfactant can prevent electrode from fouling. ${ }^{34,35}$

Keeping the above knowledge in mind, the goal of the current work is to throw more light upon the oxidation behavior of PAN on a PGE. The analytical performance of proposed method will also be demonstrated in the presence of cationic surfactant (cetyltrimethylammonium bromide, CTAB), and applied on quantification of PAN in pharmaceutical and urine samples. Although, in a very recent paper, the voltammetric determination of PAN has been studied on PGE in weakly acid/anionic surfactant solution, ${ }^{26}$ this approach reports the electrochemical investigation of PAN on the same electrode in the case of neutral solution containing cationic surfactant to enhance the stability of the compound.

\section{Experimental}

\section{1. Chemicals and Apparatus}

PAN (as sodium sesquihydrate salt) standard was purchased from Sigma. Tablet dosage form containing the active compound was procured from local pharmacy. Standard stock solutions of PAN $\left(2.4 \times 10^{-3} \mathrm{M}\right)$ were prepared daily in methanol/water $(1: 1, v / v)$ mixture, and kept refrigerated when not in use. All other chemicals used in this study were of reagent grade, and their solutions were prepared in distilled water except uric acid (prepared in $0.1 \mathrm{M}$ sodium hydroxide). Britton-Robinson (BR) buffer solutions (equal volumes of acetic acid, phosphoric acid and boric acid (each $0.04 \mathrm{M}$ ) were mixed, and adjusted to the desired $\mathrm{pH}$ between $3.0-10.0$ with $3 \mathrm{M} \mathrm{NaOH}$ ) were used for preparing more diluted solutions of PAN. The surfactants tested were anionic type, sodium dodecylsulfate (SDS), and cationic type, cetyltrimethylammonium bromide (CTAB). They were prepared by dissolving the necessary quantity of reagent in water. Ultra pure water, purified by a Milli-Q system from Millipore, was used to prepare the solutions. All experiments were carried out at the room temperature of the laboratory.

All the voltammetric measurements of cyclic voltammetry $(\mathrm{CV})$ and square-wave adsorptive stripping voltammetry (SW-AdSV) were operated using an Autolab electrochemical analyzer (Metrohm, The Netherlands) controlled with the NOVA 2.1.3 version. A three-electrode-system in a $10-\mathrm{mL}$ one-compartment voltammetric cell was employed consisting of a PGE as working electrode, an $\mathrm{Ag} /$ $\mathrm{AgCl}(3 \mathrm{M} \mathrm{NaCl}, \mathrm{MF} 2012, \mathrm{BASi})$ as reference electrode, and a Pt wire (MW 1032, BASi) as auxiliary electrode.

For the preparation of $\mathrm{PGE},{ }^{36}$ a mechanical pencil Model T 0.5 (Rotring, Germany) used as a holder, and pencil leads (Tombo, Japan) with a total length of $60 \mathrm{~mm}$ and a diameter of $0.5 \mathrm{~mm}$ were purchased from a local bookstore. The electrical contact of the lead was carried out by wrapping a metal wire around the metallic part of the pencil. A total of $7 \mathrm{~mm}$ of lead was immersed in solution per measurement. The surface of PGE was pretreated by applying a potential of $+1.40 \mathrm{~V}$ for $30 \mathrm{~s}$ in supporting electrolyte without stirring in order to increase effective surface area of the electrode and typical characteristic of electron transfer. Each measurement was performed using a new pencil surface.

\section{2. Sample Preparation}

Protonex ${ }^{\circledR}$ enteric-coated tablets containing $45.10 \mathrm{mg}$ of PAN sodium sesquihydrate (equivalent to $40 \mathrm{mg}$ PAN), were used in analytical application for this study. Ten tablets were weighed and the average mass per tablet was calculated. The tablets were thoroughly crushed in a porcelain mortar. An adequate amount of the resulting powder was transferred into a $25-\mathrm{mL}$ calibrated dark flask, filled to the mark with a mixed solution of methanol and water $(1: 1$, $v / v$ ), and sonicated for about $30 \mathrm{~min}$ to achieve the complete dissolution. An aliquot of the supernatant liquid was transferred to the voltammetric cell containing $10 \mathrm{~mL}$ of BR buffer, $\mathrm{pH} 7.0$ in the presence of $3 \times 10^{-4} \mathrm{M}$ CTAB.

Drug-free human urine samples were collected from healthy donor (male, age 25 years) before the day of the experiment. $4.90 \mathrm{~mL}$ of acetonitrile and $0.1 \mathrm{~mL}$ of PAN stock solution $\left(2.4 \times 10^{-3} \mathrm{M}\right)$ were mixed and completed to $10 \mathrm{~mL}$ with the urine sample. The tube was vortexed for about $3 \mathrm{~min}$ and then centrifuged at $4500 \mathrm{rpm}$ for $5 \mathrm{~min}$. Appropriate volume of the final mixture was transferred into the voltammetric cell containing $10 \mathrm{~mL}$ of same supporting electrolyte mentioned above. All experiments were examined in triplicate, and quantification of PAN 
was used by the standard addition method to decrease matrix effects from the urine components.

\section{Results and Discussion}

At first, $\mathrm{CV}$ technique was used at different scan rates to test commercially available pencil leads as tools for the working electrodes. Fig. 2 shows the $\mathrm{CV}$ responses of $\mathrm{PGE}$ in $0.5 \mathrm{M} \mathrm{KCl}$ in the presence of $10 \mathrm{mM} \mathrm{K}_{3} \mathrm{Fe}(\mathrm{CN})_{6}$ as a redox probe. The electroactive surface area of PGE was evaluated by using Randles-Sevcik formula (1). ${ }^{37}$

$$
i_{\mathrm{p}}=\left(2.69 \times 10^{5}\right) n^{3 / 2} A D_{0}{ }^{1 / 2} v^{1 / 2} C_{0}
$$

where $i_{\mathrm{p}}$ refers to the anodic peak current, $n$ is the number of electrons transferred, $A$ is the dynamic surface area of electrode, $D_{0}$ is the diffusion coefficient, $v$ is the scan rate, and $C_{0}$ is the concentration of $\mathrm{K}_{3} \mathrm{Fe}(\mathrm{CN})_{6}$. From the slope of the plot of $i_{\mathrm{p}}$ vs. $v^{1 / 2}$ (Fig. 2), the dynamic surface area of electrode was calculated to be $0.078 \mathrm{~cm}^{2}$ for PGE.

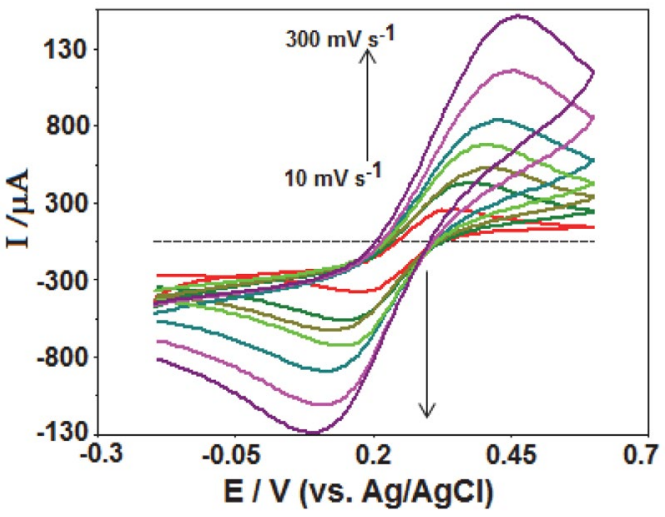

Figure 2. Electroactive surface area of PGE evaluated using cyclic voltammetry. Scan rate; $10-300 \mathrm{mV} \mathrm{s}^{-1}$.

In order to investigate the electrochemical response of PAN at PGE, the experiments were initially executed by means of CV at a scan rate of $100 \mathrm{mV} \mathrm{s}^{-1}$ in BR buffer at $\mathrm{pH}$ 7.0 (most suitable medium for analytical purposes, as shown later). As can be seen in Fig. 3, the three consecutive CVs were recorded for $2.4 \times 10^{-5} \mathrm{M}$ PAN within the potential window from $+0.5 \mathrm{~V}$ to $+1.4 \mathrm{~V}$. A cyclic voltammogram without PAN was also plotted in the graphs for comparison. PAN was oxidized in the medium yielding one main oxidation peak (presented as I) at $+1.04 \mathrm{~V}$. The presence of barely detectable secondary process (presented as II) was also observed at about $+1.2 \mathrm{~V}$ (observed more clearly on the original curves). Although such a kind of behavior was described for the oxidation of PAN at $\mathrm{pH}>6$ on carbon paste electrode ${ }^{21}$ however, the second oxidation step has not been reported in earlier studies performed by using the bare and modified PGEs. The absence of any peak in the cathodic direction indicates that the oxidation process is irreversible.

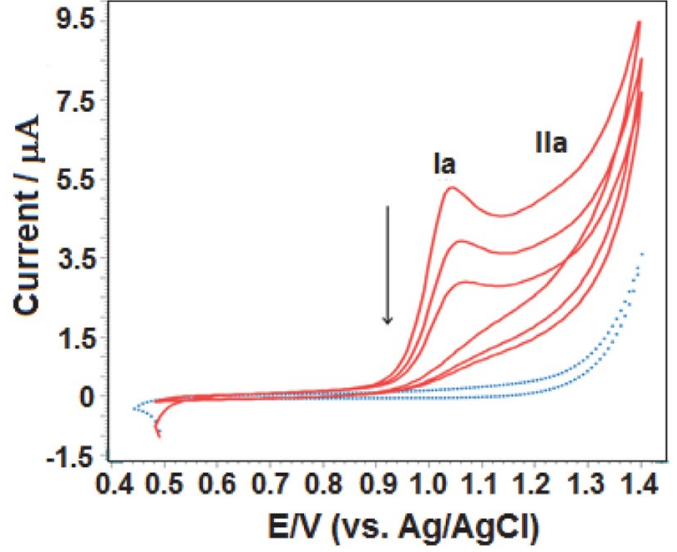

Figure 3. The repetitive cyclic voltammograms of $2.4 \times 10-5 \mathrm{M}$ pantoprazole in BR buffer, $\mathrm{pH} 7.0$ at scan rate of $100 \mathrm{mV} \mathrm{s}^{-1}$. Electrode, PGE. Dashed lines represent background current.

From the figure, it is seen that the current intensity of oxidation peak showed a decrease during the successive scans, which may be due to the adsorption of PAN and/or its oxidation products that occurs on the electrode surface.

To examine the influence of scan rate between 25 and $600 \mathrm{mV} \mathrm{s}^{-1}$ on anodic oxidation peak current and potential of PAN, CVs of $2.4 \times 10^{-5} \mathrm{M}$ PAN were recorded in BR buffer at $\mathrm{pH} 7.0$ (Fig.4). By increasing the scan rate, there was a slight shift of the oxidation peak potentials towards more positive values, confirming that this behavior is characteristic for irreversible processes. ${ }^{38}$ As seen in Fig. 4 , the response of secondary oxidation step IIa was increased at scan rate of $400 \mathrm{mV} \mathrm{s}^{-1}$.

Since the primary oxidation step Ia was sharper and easily measurable, the parameters of this step were determined for further studies.

There was a linear relationship between the oxidation peak current $\left(i_{\mathrm{p}}\right)$ and scan rate $(v)$, which reveals that the electrode process is surface-controlled. The equation is noted below:

$i_{\mathrm{p}}(\boldsymbol{\mu} \mathbf{A})=0.015 v\left(\mathrm{mV} \mathrm{s}^{-1}\right)+0.75(n=6 ; r=0.998)$

In order to better understand the PAN oxidation onto PGE, plots were constructed between the logarithm of peak current $\left(\log i_{\mathrm{p}}\right)$ and $\operatorname{logarithm}$ of scan rate $(\log v)$. In this case, it was also obtained a linear relationship according to the following equation:

$$
\begin{aligned}
& \log i_{\mathrm{p}}(\mu \mathrm{A})=0.710 \log v\left(\mathrm{mV} \mathrm{s}^{-1}\right)-1.017 \\
& (n=6 ; r=0.995)
\end{aligned}
$$

As can be seen from the equation, the value of the slope is between the theoretical value of 0.5 for diffusionand 1.0 for adsorption-controlled process. ${ }^{37}$ These facts indicate that PAN oxidation process is controlled by adsorption at PGE. 


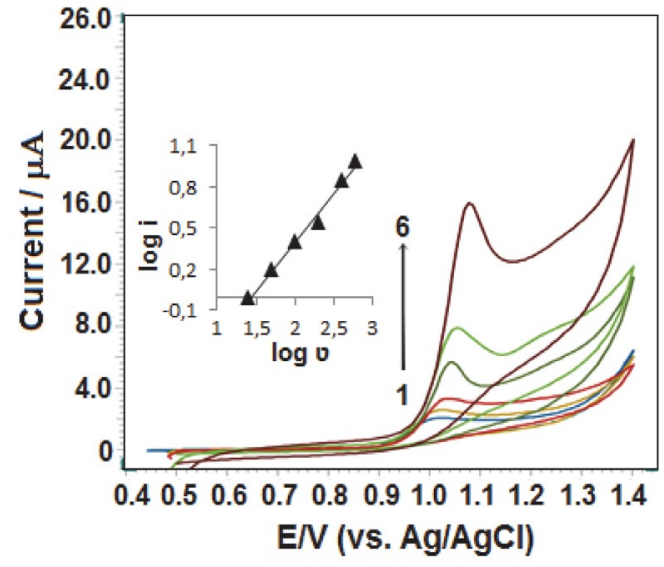

Figure 4. The cyclic voltammograms of $2.4 \times 10^{-5} \mathrm{M}$ pantoprazole in BR buffer, pH 7.0 at different scan rates $\left(1^{-6}: 25,50,100,200,400\right.$, $600 \mathrm{mV} \mathrm{s}^{-1}$ ). Electrode, PGE. Inset depicts the plot of log ip vs. $\log \mathrm{v}$.

In the light of above outcomes, AdSV studies were performed with an accumulation step to investigate the PAN oxidation process at different $\mathrm{pHs}$. In Fig. 5, this parameter was established in the range from $\mathrm{pH} 3.0-10.0$ of BR buffer by carrying out stripping measurement on $2.4 \times$ $10^{-6} \mathrm{M}$ PAN, with an open-circuit accumulation at $30 \mathrm{~s}$. It should be noted that at $\mathrm{pH}$ values lower than 3.0, well-defined peak shapes were not observed which could be due to the instability of PAN and its decomposition to other degradation products. The plot of the $E_{\mathrm{p}}$ versus $\mathrm{pH}$ (Fig. 5, inset) showed a straight line between $\mathrm{pH} 3.0$ and 7.0, which can be expressed by the following equation:

$$
E_{\mathrm{p}}(\mathrm{V})=-0.062 \mathrm{pH}+1.50(n=5 ; r=0.993)
$$

The slope of this equation was found to be $-62 \mathrm{mV} /$ $\mathrm{pH}$ units, which is close to the theoretical value of -59 $\mathrm{mV}$. This finding shows that the numbers of electrons and protons participating in the electrode reaction are equal. As can be seen from the figure, the $\mathrm{pH}$ did not indicate a significant change in the peak potential between $\mathrm{pH} 7.0$ and 8.0. After that, the peak potential shifted slightly to less positive potential value with increasing $\mathrm{pH}$ up to 9.0 , and then did not change again remarkably. The intersection point of the curves $(\sim \mathrm{pH}$ 7.0 and 8.0) is close to the $\mathrm{p} K_{\mathrm{a} 3}$ (will be given later), and it can be explained by changes in protonation of the acid-base functional groups in the benzimidazole moiety. On the other hand, the clear change in the peak intensity was also observed at about pH 7.0. From the above results, and considering the report dealing with the electrochemical oxidation of a structurally related compound omeprazole at glassy carbon electrode, ${ }^{39}$ we may assume that the primary oxidation step Ia represents one-electron and one-proton process of PAN to the formation of hydroxylated species.

Since the highest response $(11.33 \mu \mathrm{A})$ was obtained at $\mathrm{pH} 7.0$ with the peak potential of $+1.06 \mathrm{~V}$, this condition

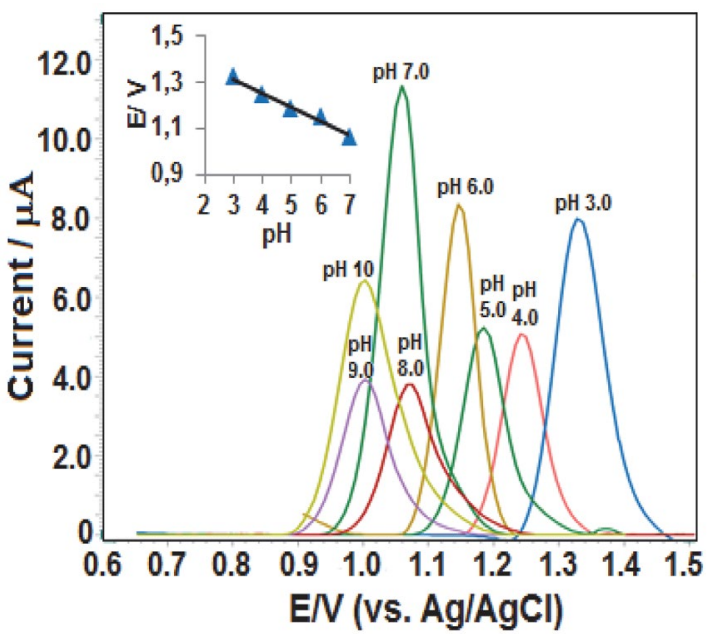

Figure 5. The stripping voltammograms of $2.4 \times 10^{-6} \mathrm{M}$ pantoprazole in BR buffer, $\mathrm{pH} 3^{-10}$. Electrode, PGE. AdSV conditions: accumulation time $30 \mathrm{~s}$ at open-circuit condition. SWV parameters: frequency, $50 \mathrm{~Hz}$; step potential, $8 \mathrm{mV}$; pulse amplitude, $30 \mathrm{mV}$. Inset depicts the plot of Ep vs. pH.

was selected for further experiments and development of the methodology.

Taking into account the noticeable adsorptive features of PAN at the surface of PGE, the attention was then turned to the effect of pre-concentration/stripping conditions to enhance the sensitivity of analytical methodology. The influence of the accumulation time $\left(t_{\mathrm{acc}}\right)$ upon the oxidation peak signal was examined in the range $0-240 \mathrm{~s}$ at open-circuit condition for $2.4 \times 10^{-6} \mathrm{M}$ PAN in BR buffer $\mathrm{pH} 7.0$ (data not shown). The intensity of oxidation peak current increased gradually with $t_{\text {acc }}$ until $30 \mathrm{~s}$ beyond which the peak current remained nearly constant. This result shows that the electrode surface is saturated with PAN molecules. Next, the dependence of the stripping peak current on $E_{\text {acc }}$ was evaluated at open-circuit conditions and over the potential range +0.1 to $+0.6 \mathrm{~V}$ with $t_{\mathrm{acc}}$ of 30 $\mathrm{s}$. The maximum peak current was achieved at the potential of the open-circuit condition. Therefore, $t_{\text {acc }}$ and $E_{\text {acc }}$ of $30 \mathrm{~s}$ and open-circuit condition were applied in succeeding analytical investigations.

In the following step, to optimize the experimental set-up for PAN determination, the dependence of stripping responses on other parameters such as frequency ( $f=$ $15-125 \mathrm{~Hz})$, scan increment $\left(\Delta E_{\mathrm{s}}=4-12 \mathrm{mV}\right)$ and pulse amplitude $\left(\Delta E_{\mathrm{sw}}=10-60 \mathrm{mV}\right)$ were analyzed. Taking into account the repeatability, baseline stability, accuracy, and magnitude of the analytical signal at the PGE for PAN determination, optimal values of $f, 50 \mathrm{~Hz} ; \Delta E_{\mathrm{s}}, 8 \mathrm{mV}$; and $\Delta E_{\mathrm{sw}}, 50 \mathrm{mV}$ were obtained.

Finally, the effects of cationic (positively charged) surfactant, CTAB, and anionic (negatively charged) one, SDS were also evaluated on the ease of the oxidation of PAN. Keeping the PAN concentration constant at $2.4 \times$ $10^{-7} \mathrm{M}$, surfactants were added to BR buffer, $\mathrm{pH} 7.0$ having different concentrations in the range from $1 \times 10^{-5} \mathrm{M}$ to 5 
$\times 10^{-4} \mathrm{M}$. When the solution contained cationic-CTAB, PAN stripping peak current increased with CTAB concentration up to $3 \times 10^{-4} \mathrm{M}$, after this concentration value a decrease in oxidation peak current was remarked (data not shown). Whereas the electrolyte solution containing anionic-SDS, the peak current was found to decrease with a shift slightly towards more positive values. Fig. 6 shows comparison of stripping voltammograms in the presence of CTAB and SDS having concentrations of $3.0 \times 10^{-4} \mathrm{M}$ and $4.0 \times 10^{-4} \mathrm{M}$, respectively, at which maximum peak intensities were obtained. To sum up, the concentration of $\mathrm{CTAB}$ at $3 \times 10^{-4} \mathrm{M}$ was chosen for the rest of present analytical investigation. In this case, PAN signals were almost 2.5 times higher than those obtained in surfactant-free solution.

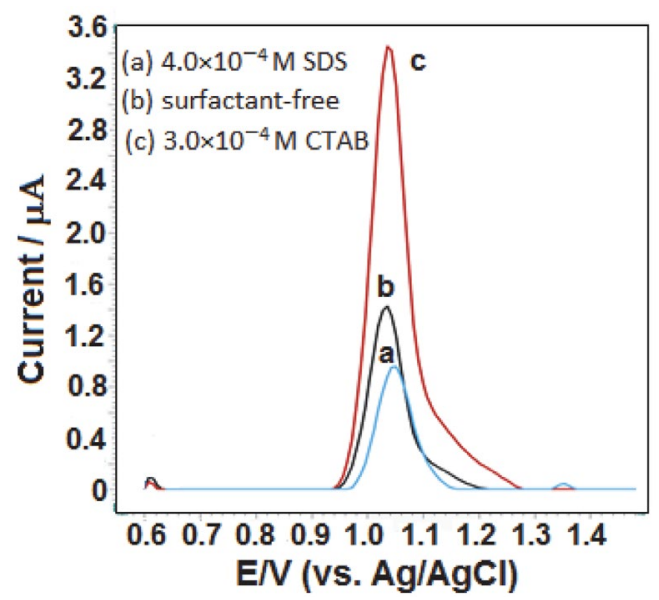

Figure 6. The stripping voltammograms of $2.4 \times 10^{-7} \mathrm{M}$ pantoprazole in BR buffer, $\mathrm{pH} 7.0$ in the absence and presence of surfactants. Electrode, PGE. AdSV conditions: accumulation time $30 \mathrm{~s}$ at open-circuit condition. SWV parameters: frequency, $50 \mathrm{~Hz}$; step potential, $8 \mathrm{mV}$; pulse amplitude, $50 \mathrm{mV}$.

The estimated $\mathrm{p} K_{\mathrm{a}}$ values of PAN have been reported to be $\mathrm{p} K_{\mathrm{a} 1} \approx 0.11$ (for the protonation of the benzimidazole $\mathrm{N} 3$ ), $\mathrm{p} K_{\mathrm{a} 2} \approx 3.9$ (for the protonation of the N-pyridine), $\mathrm{p} K_{\mathrm{a} 3} \approx 8.2$ (for the deprotonation of the benzimidazole-NH). ${ }^{40,41}$ Thus the compound can exist in four different ionic forms in aqueous electrolytes such as dicationic, cationic, neutral, and anionic species. The previously published papers reported that dicationic form of structurally related PPIs is very unstable. ${ }^{42}$ In studied condition (at pH 7.0), PAN molecule exists as a mixture of uncharged $(\sim 75 \%)$ and partly negatively charged ( $25 \%)$ forms. Considering the critical micelle concentration of $\mathrm{CTAB}$, $\mathrm{CMC}_{\mathrm{CTAB}}=8.7 \times 10^{-4} \mathrm{M},{ }^{43}$ at relatively higher concentration of surfactant (in our case $3 \times 10^{-4} \mathrm{M}$ ) added to the solution, the surface micelles are formed on the electrode surface. Therefore, it is expected that adsorption on the electrode surface is mainly maintained by hydrophobic interaction between neutral PAN molecules $(\sim 75 \%)$ and long hydrophobic tails of CTAB which dominates the coadsorption of PAN with CTAB on PGE surface. Addition- ally, the electrostatic interaction between negatively charged PAN molecules ( 25\%) and oppositely charged head groups of the CTAB may also occur. Thus, these strong interactions result in a maximum increase in analytical signal. In the case of anionic-SDS, the electrostatic force works in the opposite direction, thus causes the decrease of peak intensity.

It is also important to underline that in a previous study published very recently, ${ }^{26}$ the voltammetric determination of PAN have been carried out using PGE in supporting electrolyte solutions at $\mathrm{pH} 6.0$ containing anionic surfactant, SDS. In that study, the nature of the interaction between PAN and SDS molecules was ascribed to the effect of electrostatic PAN-SDS. However, at pH 6.0 neutral form of PAN predominates in the supporting electrolyte. In this case, the hydrophobic interactions between PAN and SDS are more pronounced comparing to the electrostatic attractive interaction. The authors reported that in the presence of cationic and non-ionic surfactants, the increase with different degrees in the peak currents was also observed as compared with the value obtained in their absence. These results provide further evidence that the hydrophobicity of PAN induce interaction with all kinds of surfactants that possess a long-chain hydrophobic group.

After optimization of chemical conditions and instrumental parameters, PGE combined with SW-AdSV could allow for analyzing PAN in BR buffer, $\mathrm{pH} 7.0$ containing $3 \times 10^{-4} \mathrm{M} \mathrm{CTAB}$. The stripping responses given in Fig. 7 displayed that the dependence of oxidation peak currents on the PAN concentration was linear, in the range of $2.4 \times 10^{-8}-7.1 \times 10^{-7} \mathrm{M}\left(9.2-272 \mu \mathrm{g} \mathrm{L}^{-1}\right)$. The oxidation peak current at a potential of $+1.05 \mathrm{~V}$ increased continually with its concentration (Fig. 7, inset) to yield a highly linear calibration plot; $i_{\mathrm{p}}(\mu \mathrm{A})=27.477 C(\mu \mathrm{M})+0.223(r$ $=0.999, n=7)$, where $i_{\mathrm{p}}$ is the stripping peak current, $C$ the

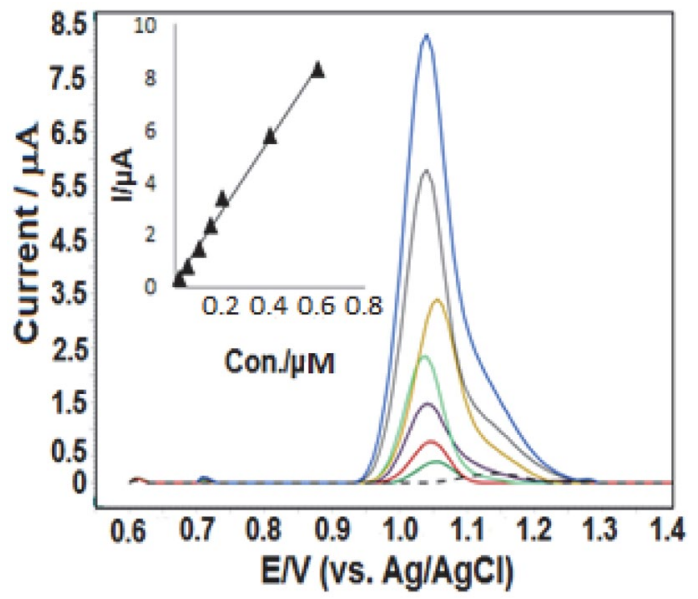

Figure 7. The stripping voltammograms for pantoprazole levels of (1) 0.024, (2) 0.06 , (3) 0.12, (4) 0.19 , (5) 0.24 , (6) 0.48 and (7) 0.71 $\mu \mathrm{M}$ in BR buffer, $\mathrm{pH} 7.0$ in the presence of $3 \times 10^{-4} \mathrm{M}$ CTAB. Dashed lines represent background current. Inset depicts a corresponding calibration plot for the quantitation of pantoprazole. Other operating conditions as indicated in Fig. 6. 
Table 1. Comparison of the analytical performance of PGE for the determination of pantoprazole with literature electrodes.

\begin{tabular}{|c|c|c|c|c|c|}
\hline Electrode & $\begin{array}{l}\text { Supporting } \\
\text { electrolyte }\end{array}$ & Technique & $\begin{array}{l}\text { LOD } \\
(\mathrm{M})\end{array}$ & Sample & Ref. \\
\hline HMDE & BR, pH 7.0 & SW-AdCSV & $5.0 \times 10^{-10}$ & Pharmaceuticals & 18 \\
\hline HMDE & $\mathrm{BR}, \mathrm{pH} 5.0$ & SWV & $1.3 \times 10^{-7}$ & Pharmaceuticals, human plasma & 19 \\
\hline $\mathrm{SbF} / \mathrm{GCE}$ & BR, pH 5.0 & SWV & $9.1 \times 10^{-7}$ & Pharmaceuticals & 20 \\
\hline CPE & $\mathrm{BR}, \mathrm{pH} 4.0$ & DP-AdSV & $2.0 \times 10^{-8}$ & Pharmaceuticals & 21 \\
\hline GCE & $\mathrm{BR}, \mathrm{pH} 5.0$ & DPV & $4.0 \times 10^{-7}$ & Pharmaceuticals, human plasma & 22 \\
\hline \multirow[t]{3}{*}{ GCE } & $\mathrm{BR}, \mathrm{pH} 8.0$ & DPV & $3.7 \times 10^{-7}$ & Pharmaceuticals, human urine & 23 \\
\hline & & SWV & $1.8 \times 10^{-7}$ & Anodized EPPG & \\
\hline & BR, pH 5.0 & DPV & $4.1 \times 10^{-9}$ & Pharmaceuticals, human urine & 24 \\
\hline PGE & BR, pH 7.0 & $\begin{array}{l}\text { Complexation } \\
\text { based SW-AdSV }\end{array}$ & $4.0 \times 10^{-11}$ & Rabbit plasma & 25 \\
\hline PGE & $\mathrm{BR}, \mathrm{pH} 6.0+\mathrm{SDS}$ & SW-AdSV & $2.0 \times 10^{-9}$ & Rabbit plasma & 26 \\
\hline EBT/PGE & $\mathrm{BR}, \mathrm{pH} 7.0$ & SW-AdSV & $1.2 \times 10^{-8}$ & Human serum & 27 \\
\hline BCG/PGE & $\mathrm{BR}, \mathrm{pH} 7.0$ & SW-AdSV & $2.2 \times 10^{-8}$ & Pharmaceuticals, rabbit plasma & 28 \\
\hline SWCNTs/CPE & PBS, pH 7.0 & SWV & $4.9 \times 10^{-10}$ & $\begin{array}{l}\text { Pharmaceuticals, human serum } \\
\text { and urine }\end{array}$ & 29 \\
\hline PGE & BR, pH $7.0+$ CTAB & SW-AdSV & $7.0 \times 10^{-9}$ & Pharmaceuticals, human urine & This work \\
\hline
\end{tabular}

PAN concentration, $r$ the correlation coefficient, and $n$ the number of experiments.

From this plot obtained by the analytical curves, the limit of detection (LOD) and quantification (LOQ) were calculated using the formulae $3.3 \mathrm{~s} / \mathrm{m}$ and $10 \mathrm{~s} / \mathrm{m}$, respectively, where $s$ is the standard deviation of the response of the lowest concentration of the linearity range (three replicate measurements), and $m$ the slope of the related calibration equation. By using these formulae, the LOD and LOQ were found to be $7.0 \times 10^{-9} \mathrm{M}\left(2.7 \mu \mathrm{g} \mathrm{L}^{-1}\right)$ and $2.1 \times 10^{-8} \mathrm{M}$ $\left(8.1 \mu \mathrm{g} \mathrm{L}^{-1}\right)$, respectively.

Table 1 compares the analytical performance of the PGE with some electrodes (mercury, carbon-based modified and unmodified ones) in previously published papers.

From these data, it can be seen that some electrodes ${ }^{19,20-23,27,28}$ reported in literature declare lower sensitivity than the PGE (used in this study). However, PGE showed a less sensitive voltammetric response than some mercury $^{18}$ and carbon-based ${ }^{24,25,29}$ electrodes. Despite the higher sensitivity of HMDE, because of its toxicity mercury electrodes are not environmentally friendly. On the other hand, modified carbonaceous electrodes have a long-time preparation, poor reproducibility, and high costs. Slightly lower LOD value was found for the PGE in acidic/anionic-SDS media (previous study) ${ }^{26}$ than in the presence of cationic-CTAB (this work). However, the measurement in neutral solutions reduces the risk of decomposition of PAN.
The precision of the developed method was calculated by intra-day repeatability (six experiments within the same day) and inter-day repeatability (three assays for five days from different solutions) by successive measurements of $6.0 \times 10^{-8} \mathrm{M}$ PAN. The relative standard deviation (RSD) values were $2.56 \%$ (peak current) and $1.09 \%$ (peak potential) for intra-day repeatability, and $3.57 \%$ (peak current) and 1.65\% (peak potential) for inter-day repeatability.

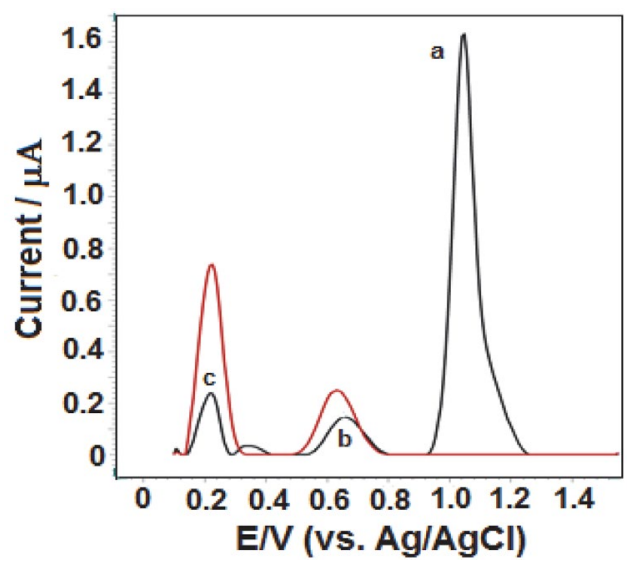

Figure 8. The stripping voltammograms of $1.2 \times 10^{-7} \mathrm{M}$ pantoprazole (a) in the presence of $6.0 \times 10^{-7} \mathrm{M}$ uric acid (b) and $5.3 \times 10^{-7}$ $\mathrm{M}$ dopamine (c). Red line represents the mixture solutions of uric acid at the same concentrations. Supporting electrolyte, BR buffer, $\mathrm{pH} 7.0$ in the presence of $3 \times 10^{-4} \mathrm{M}$ CTAB. Other operating conditions as indicated in Fig. 6. 
Taking into account that PAN is fairly unstable at low pHs, working solutions prepared in acidic medium were run and analyzed during a maximum period of $1 \mathrm{~h}$.

The possible interferences of some compounds commonly found in pharmaceutical samples were evaluated via the electrochemical oxidation of $1.2 \times 10^{-7} \mathrm{M}$ PAN in BR buffer solution, $\mathrm{pH}$ 7.0. A 10-fold excess of inorganic ions such as $\mathrm{K}^{+}, \mathrm{Na}^{+}, \mathrm{Ca}^{2+}, \mathrm{Cl}^{-}$, and $\mathrm{I}^{-}$, and sugars such as glucose and fructose did not significantly influence the current response of PAN (data not shown).

The interferences of commonly identified biomolecules in urine, such as uric acid $\left(6.0 \times 10^{-7} \mathrm{M}\right)$ and dopamine $\left(5.3 \times 10^{-7} \mathrm{M}\right)$ were tested for $1.2 \times 10^{-7} \mathrm{M}$ PAN, and the corresponding stripping curves are depicted in Fig. 8. The oxidation peaks of dopamine and uric acid appeared at about +0.23 and $+0.63 \mathrm{~V}$, respectively, thus insignificantly affecting the oxidation signal of PAN at $+1.05 \mathrm{~V}$. Taking the results together, the developed method for PAN determination could also be applied to analyze urine samples.

In the light of above findings, proposed methodology was applied to analyze the content of PAN in commercially available tablet form by using calibration method. Samples were prepared as described in the experimental section, without extraction, evaporation or filtration, and adequately diluted. For this formulation, the assay results were in good agreement with the declared content (Table 2). In order to detect the interaction between the excipients and PAN, recovery studies were carried out adding standard PAN solutions to the sample solution in voltammetric cell and followed by analysis using the proposed method. Recovery of PAN was calculated by comparing the concentration obtained from the spiked mixtures with those of the pure compound. As seen in Table 2, the results indicate the absence of matrix interference effect in tablet dosage forms.

Table 2. Pantoprazole content and mean recoveries in tablet dosage form (Protonex ${ }^{\oplus}$ tablets) obtained by SW-AdSV

\begin{tabular}{lc}
\hline Labelled claim/mg & 40 \\
Amount found $/ \mathrm{mg}$ & 41.05 \\
RSD \% & 2.8 \\
Bias \% & -2.6 \\
Average recovery $\%$ & 102 \\
RSD of recovery \% & 3.7 \\
Bias \% & -2.0 \\
\hline
\end{tabular}

${ }^{a}$ Mean of five experiments ${ }^{b}$ Mean of three experiments
The satisfactory analytical sensitivity of the proposed method was also tested in urine sample that is a more complex matrix in comparison with pharmaceutical formulations. To eliminate the effect of interfering substances such as proteins, the urine samples were first treated with acetonitrile, and centrifuged. The determination of PAN in the spiked urine sample was performed by means of the standard addition method (data not shown). An oxidation peak appeared at about $+1.07 \mathrm{~V}$ which could be due to the oxidation of PAN since its peak current increased after each standard addition of this compound. In the absence of PAN, there were no detectable oxidation peaks in the working potential range where the analytical peak was observed. On the other hand, an unknown oxidation peak at about $+0.65 \mathrm{~V}$ was observed in blank urine samples due to the oxidation of uric acid. As can be seen in Table 3, the acquired result is consistent with the added amount of PAN, and satisfactory recovery and RSD are the evidence of the accuracy of the method.

\section{Conclusion}

In the present study, a new electrochemical methodology using modification-free PGE in aqueous and aqueous/surfactant solutions was established, which was rapid, simple, precise, accurate, and having lover risk of decomposition errors. The proposed method was applicable directly to the routine quality control of pharmaceutical formulation after dissolution of the samples, eliminating any use of organic reagents or expensive apparatus. The presented study was also intended to show the possibility of monitoring PAN in human urine samples.

\section{References}

1. R. Huber, M. Hartman, H. Bliesath, R. Lühmann, and V. W. Steinijans, Int. J. Clin. Pharmacol. Ther. 1996, 35, 185-194.

2. J. M. Shin, N. Kim, J. Neurogastroenter. Mot. 2013, 19, 25-35. DOI:10.5056/jnm.2013.19.1.25

3. Q. B. Cass, A. L. G. Degani, N. M. Cassiano, J. Pedrazolli, J. Chromatogr B 2002, 766, 153-160.

DOI: $10.1016 /$ S0378-4347(01)00472-8

4. C. J. Shih, Y. T. Chen, S.M. Ou, S. Y. Li, T. J. Chen, S. J. Wang, Int. J. Cardiol. 2014, 177, 292-297.

DOI:10.1016/j.ijcard.2014.09.036

Table 3. The results for addition and recovery of pantoprazole from urine sample using SW-AdSV.

\begin{tabular}{ccc}
\hline Added $/\left(\boldsymbol{\mu g ~ \mathbf { ~ m } ^ { - 1 } )}\right.$ & Found $^{\mathrm{a}} /\left(\boldsymbol{\mu \mathbf { g ~ m L } ^ { - 1 } )}\right.$ & Recovery $^{\mathrm{a}} \mathbf{\%} \mathbf{R S D} \%$ \\
\hline 0.025 & 0.024 & $96.00 \pm 4.27$ \\
0.050 & 0.048 & $96.00 \pm 3.90$
\end{tabular}

${ }^{\text {a }}$ Calculated by the use of standard addition method. Values reported are the average of three independent analysis of the same sample. 
5. O. Peres, C. H. Oliveira, R. H. Barrientos-Astigarraga, V. M. Rezende, G. D. Mendes, G. Nucci, Arzneimittelforschung 2004, 54, 314-319. DOI:10.1055/s-0031-1296977

6. B. Patel, M. Patel, J. Patel, B. Suhagia, J. Liq. Chrom. Rel. Technol. 2007, 30, 1749-1762.

DOI:10.1080/10826070701360368

7. S. Thanikachalam, M. Rajappan, V. Kannappan, Chromatographia 2008, 67, 41-47. DOI:10.1365/s10337-007-0452-y

8. O. Rahić, E. Vranić, I. Mujezin, J. Hadžiabdić, A. Elezović, Int. J. Pharm. Teach. Prac. 2013, 4, 793-796.

9. S. Pandey, P. Pandey, D. Mishra, U. K. Singh, Braz. J. Pharm. Sci. 2013, 49, 175-184.

DOI:10.1590/S1984-82502013000100019

10. P. Zhao, M. Deng, P. Huang, J. Yu, X. Guo, L. Zhao, Anal. Bioanal. Chem. 2016, 408, 6381-6392. DOI:10.1007/s00216-016-9753-Z

11. J.B. Nagavi, H. Joshi, B. Gurupadayya, Int. J. Pharm. Res. Health Sci. 2018, 6, 2690-2700.

12. V. Srinandan, K. Nagappan, S. Patel, K. Yamjala, G. Byran, B. Babu, Curr. Pharm. Anal. 2019, 15, 17-23. DOI:10.2174/1573412914666180101142646

13. I. Süslü, S. Altınöz, E. Yıldız, FABAD J. Pharm. Sci. 2003, 28, 85-92.

14. F. Salama, N. Abasawy, S. A. A. Razeq, M. M. F. Ismail, M. M. J. Fouad, J.Pharm. Biomed. Anal. 2003, 33, 411-421. DOI:10.1016/S0731-7085(03)00233-4

15. N. K. Ramadan, N. A. El-Ragehy, M. T. Ragab, B. A. El-Zeany, Spectrochim. Acta A Mol. Biomol. Spectrosc. 2015, 137, 463470. DOI:10.1016/j.saa.2014.09.003

16. J. Guan, F. Yan, S. Shi, S. Wang, Electrophoresis 2012, 33, 1631-1636. DOI:10.1002/elps.201100650

17. G. Hancu, L. A. Papp, A. Rusu, Chromatographia 2015, 78, 279-284. DOI:10.1007/s10337-014-2827-1

18. A. Radi, J. Pharm. Biomed. Anal. 2003, 33, 687-692. DOI:10.1016/S0731-7085(03)00356-X

19. S. Altınöz, I. Suslu, Anal. Lett. 2005, 38, 1389-1404. DOI:10.1081/AL-200062195

20. B. Nigovic, S. B. Hocevar, Electrochim. Acta 2013, 109, 818822. DOI:10.1016/j.electacta.2013.07.173

21. A. Radi, Il Farmaco 2003, 58, 535-539. DOI:10.1016/S0014-827X(03)00082-X

22. N. Erk, Anal. Biochem. 2003, 323, 48-53. DOI:10.1016/j.ab.2003.08.023

23. A. M., Elsied, G. G.Mohamed, Int. J. Electrochem. Sci. 2015, 10, 7147-7158.
24. M. Hadi, A. Ehsani, S. Afr. J. Chem. 2016, 69, 79-87. DOI:10.17159/0379-4350/2016/v69a10

25. P. Y. Khashaba, H. R. H. Ali, M. M. El-Wekil, Electroanalysis 2017, 29, 890-897. DOI:10.1002/elan.201600639

26. P. Y. Khashaba, H. R. H., Ali, M. M. El-Wekil, J. Anal. Chem. 2019, 74, 609-616. DOI:10.1134/S106193481906008X

27. P. Y. Khashaba, H. R. H. Ali, M. M. El-Wekil, Mat. Sci. Eng. C 2017, 75, 733-741. DOI:10.1016/j.msec.2017.02.092

28. P. Y. Khashaba,H. R. H. Ali, M. M. El-Wekil, R. Soc. Open Sci. 2017, 4, 170324-170337. DOI:10.1098/rsos.170324

29. P. Manjunatha, Y. Arthoba Nayaka, H. T. Purushothama, R. O. Yathisha, M. M. Vinay, Ionics 2019, 25, 2297-2309. DOI:10.1007/s11581-018-2624-1

30. I. G. David, D.-E. Popa, M. Buleandra, J. Anal. Meth. Chem. 2017. DOI: $10.1155 / 2017 / 1905968$

31. A.-N. Kawde, N. Baig, M. Sajid, RSC Adv., 2016, 6, 9132591340. DOI:10.1039/C6RA17466C

32. M. R. Akanda, M. Sohail, M. A. Aziz, A.-N. Kawde, Electroanalysis 2016, 28, 408-424. DOI:10.1002/elan.201500374

33. R. Vittal, H. Gomathi, K. Kim, Adv. Colloid Interface Sci. 2006, 119, 55-68. DOI:10.1016/j.cis.2005.09.004

34. P. H. C. P. Tavares, P. J. S. Barbeira, J. Appl. Electrochem., 2008, 38, 827-832. DOI:10.1007/s10800-008-9518-2

35. G. K. Ziyatdinova, E. R. Ziganshina, H. C. Budnikov, J. Anal. Chem. 2017, 67, 869-879.

DOI:10.1134/S106193481211010X

36. Y. Yardım, Z. Şentürk, Talanta 2013, 112, 11-19. DOI:10.1016/j.talanta.2013.03.047

37. A. J. Bard, L. R. Faulkner, Electrochemical methods: Fundamentals and applications, 2nd ed., John Wiley\&Sons, Inc, NewYork, 2000. Wiley\&Sons, Inc, NewYork, 2000.

38. A. Levent, Y. Yardim, Z. Senturk. Electrochim. Acta 2009, 55, 190-195. DOI:10.1016/j.electacta.2009.08.035

39. S. M. A. Jorge, A. D R. Pontinha, A. M. Oliveira-Brett, Electroanalysis 2010, 22, 625-631.

DOI:10.1002/elan.200900377

40. D. Eberl, R. P. Hummel, R. Kuhn, J. Chromatogr A, 1997, 759, 185-192. DOI:10.1016/S0021-9673(96)00769-8

41. V. F. Roche, Am. J. Pharm. Educ., 2006, 70, 1-11. DOI:10.5688/aj7005101

42. R. Yang S. G. Schulman, P. J. Zavala, Anal. Chim. Acta, 2003, 481, 155-164. DOI:10.1016/S0003-2670(03)00076-X

43. F. Mutelet, M. Rogalski, M. H. Guerrnouche, Chromatographia, 2003, 57, 605-610. DOI:10.1007/BF02491736 


\section{Povzetek}

Preučevali smo elektrokemijsko oksidacijo pantoprazola, selektivnega zaviralca protonske črpalke, v vodnem mediju in v mediju voda/surfaktant na elektrodi iz grafitnega svinčnika (PGE) za enkratno uporabo. Uporabili smo ciklično voltametrijo in adsorptivno inverzno (stripping) voltametrijo. Občutljivost inverznih voltametrijskih meritev se je znatno izboljšala, če je bil v nevtralni raztopini elektrolita prisoten kationski surfaktant cetiltrimetilamonijev bromid (CTAB). $\mathrm{Za}$ analizne namene smo uporabili dobro ločene voltametrijske vrhove pri +1,05 V (vs. Ag/AgCl), ki smo jih dobili v Britton-Robinsonovem pufru pri $\mathrm{pH} 7,0$ in s koncentracijo $3 \times 10^{-4} \mathrm{M}$ CTAB ob uporabi inverzne voltametrije s pravokotnimi pulzi (po $30 \mathrm{~s}$ akumulacije v kratko sklenjenem tokokrogu). Proces lahko uporabimo za določitev koncentracije pantoprazola v območju $2,4 \times 10^{-8}-7,1 \times 10^{-7} \mathrm{M}\left(9,2-272 \mu \mathrm{g} \mathrm{L}{ }^{-1}\right) \mathrm{z}$ mejo zaznave $7,0 \times 10^{-9} \mathrm{M}\left(2,7 \mu \mathrm{g} \mathrm{L} \mathrm{L}^{-1}\right)$. Predlagano metodo smo s sprejemljivimi izkoristki uporabili za določitev pantoprazola $\mathrm{v}$ farmacevtskem pripravku in $\mathrm{v} v$ vorcih človeškega urina $\mathrm{z}$ dodanim analitom. 